\title{
THE ASEAN'S ATTITUDE TO THE SOUTH CHINA SEA DISPUTE AFTER THE VERDICT OF THE PERMANENT COURT OF ARBITRATION IN THE HAGUE
}

\section{THE IMPORTANCE OF THE SOUTH CHINA SEA - INTRODUCTION}

The South China Sea is an area of special interest to many countries and organizations, mainly, but not only, because of its economic and transport importance. The Andaman Sea, the Strait of Malacca, Sunda and Lombok are the main transport routes connecting the Pacific Ocean with the Indian Ocean. Trade routes of Europe, Africa, the Middle East and South Asia are crossed here. The importance of this area for world trade is evidenced by the following data: the United Nations Conference on Trade and Development (UNCTAD) estimates that about 80 percent of world trade in terms of volume and 70 percent in terms of value is transported by sea. Of this volume, 60 percent of maritime trade flows through Asia, with an estimated one-third of global shipping on the South China Sea. In 2016, goods totaling USD 3.37 trillion (China Power) were transported through this area. The most frequently transported goods are crude oil and its oil products, minerals, machinery and equipment. It is worth noting that in the case of Japan, South Korea, China and Taiwan, more than 80 percent of oil supplies flow through this route (Hoang Viet, 2009, p. 278).

In addition, this area is rich in crude oil, natural gas and other minerals. According to some experts, oil fields in this area are even larger than in the Middle East, according to other expert opinions they are not so rich, nevertheless Brunei, Malaysia, Vietnam, Indonesia, China are among the largest producers of this raw material - the second and top third of the ranking, China ranks sixth (CIA, the World Factbook). The U.S. Energy Information Administration (EIA) estimates the resources of the South China Sea at 11 billion barrels of oil and 190 trillion cubic meters of natural gas as confirmed and probable reserves (Table 1) ("The New York Times", July 14, 2016).

The area is important not only because of potential deposits of energy resources, its strategic location is equally valuable - the connection of the Pacific and Indian Ocean is not only considered as trade routes, but also military security issues. Maritime economy is also important, it is a reservoir rich in fish and seafood. Therefore, all these reasons make the South China Sea an area of interest not only for the countries of the region, but also for the powers i.e. the USA, India, Japan, Russia and Australia. 
South China Sea estimated proved and probable reserves (U.S. Energy Information Administration)

\begin{tabular}{||l|c|c||}
\hline \multicolumn{1}{|c|}{ Country Name } & $\begin{array}{c}\text { Crude oil and liquids } \\
\text { reserves (billion barrels) }\end{array}$ & $\begin{array}{c}\text { Natural gas reserves } \\
\text { (trillion cubic feet) }\end{array}$ \\
\hline Brunei & 1.5 & 15 \\
\hline China & 1.3 & 15 \\
\hline Indonesia & 0.3 & 55 \\
\hline Malaysia & 5.0 & 80 \\
\hline Philippines & 0.2 & 4 \\
\hline Taiwan & - & - \\
\hline Thailand & - & 1 \\
\hline Vietnam & 3.0 & 20 \\
\hline
\end{tabular}

The area is important not only because of potential deposits of energy resources, its strategic location is equally valuable - the connection of the Pacific and Indian Ocean is not only considered as trade routes, but also military security issues. Maritime economy is also important, it is a reservoir rich in fish and seafood. Therefore, all these reasons make the South China Sea an area of interest not only for the countries of the region, but also for the powers i.e. the USA, India, Japan, Russia and Australia.

In terms of geographic distribution, ASEAN is the organization that is obviously interested in preventing the dispute from turning into an open military conflict which destroys the balance of power established in the region as little as possible. Despite China and Taiwan, all countries in the area are members of the ASEAN. A look at the conflict through the context of factors integrating/disintegrating the region, regional specificity will accompany considerations regarding the ASEAN attitude to one of the most difficult to solve and the longest lasting conflicts in this part of the world.

The theoretical basis of the analysis is regionalism. To study of the regionalism are used paradigms, which developed in the science about international relations, including realistic and neo-realistic, liberal, constructivist and behavioral theories. Each one of them changes research optics and determines research field. Many researchers analyzing contemporary regionalism uses the constructivism. It is the conceptualization of interaction between: material motives, inter-subjective structures, identity and interests of actors. Then liberal theories increase the role of the institution of co-ordinations, which bond regions. At last, the research method can be a return to research of dependences between the political economy and the necessity of the policy changes of an internal coalition of nationally-social groups which are examples of new regionalism (Hurrell, 1995, p.73). New regionalism emphasizes the necessity of applying attention on the non-state actors as important participants of this process.

For this article the most useful was the theory of neorealism, which emphasizes the anarchist international system and the struggle for political influence. Realists and neorealists emphasize the scale of the external configuration of forces. Privileges - often stimulate the emergence of regional organizations and institutions that regulate the international system. Some organizations were founded to balance the influence; others 
were created to be organizations that have a clear anti-power nature. Hurrell assumes that all regional organizations cannot be understood differently from their regional balance of power and regional dominant forces policy. In other words, regional organizations can be created as a confirmation of the balance of power in the region, but also to prevent the domination of one of the countries. ASEAN is such an organization. In the case of the South China Sea, two great powers: the USA and China have different visions about its future. In addition, ASEAN states involved in the dispute have conflicting interests. The purpose of the article is to discuss how the parties are involved in the conflict, progress towards signing the Code of Conduct for the Parties in the South China Sea and the attitude of ASEAN countries to this conflict. Due to the degree of dependence of economies on Chinese influence, the behavior of individual countries is different. Hence the problem with the organization's cohesion and attempts to break the deadlock, which have been unsuccessful so far. The basic research hypothesis that will be verified is to maintain the status quo in the South China Sea in the long run.

\section{THE PARTIES OF THE SOUTH CHINA SEA DISPUTE}

In the dispute over the Spratly archipelago, Vietnam, China, Taiwan, the Philippines, Malaysia and Brunei are the parties. Vietnam, China and Taiwan (although of course its legal situation should be looked at differently) have claims to the entire archipelago. The Philippines, which joined the conflict only in 1951, and Malaysia, which has been in a dispute since 1978, have claims to part of it. Brunei has claims only to one island of Louis Reef (since 1984) (Melitsa, Kupfer). China and Vietnam have claims to the northern islands of Paracel.

The conflict began already in 1950s, but political declarations at that time did not bring with them military actions. At the beginning of the 1970s the situation began to change. In 1974 China annexed the Paracels, using the difficult political situation of Vietnam and the ongoing at that time (until 1975) civil war, and in 1988 it took the first steps in this direction towards the Spratly archipelago. The Philippines were very active at that time. They increased the military contingent in Pag-asa, they built an airport and they began to build an active civil administration(Sobczyński, 2008, p. 107). In 1978 the Philippines took actions in the direction of proclaiming a new state on a few islands - Freedomland or Kalayaan. The attempt was not successful.

In the 1970s Malaysia made territorial claims. Initially it was the atoll James Shoal, later also Amboyna Cay, Mariveles Reef and Commodore Reef. In 1984 Brunei joined the conflict, indicating Louisa Reef in the east side of the archipelago as its possession according to the law of the sea. It is also worthwhile to note that Indonesia does not claim any island, but the Chinese claims to the exclusive economic zone cover parts of the Indonesian exclusive economic zone, covering, among others, natural gas deposits, Natuna.

Law of the sea forms the basis of the argumentation adopted by the Philippines, Brunei, Malaysia and Indonesia. On the other hand, among the parties participating in the conflict, China and Vietnam - the two biggest rivals and pretenders to the islands - use historic arguments. These are difficult to verify, especially when they intermingle with political interests. 
In the early 1990s progress was achieved as for the regulation of the conflict over the archipelagos. ASEAN states signed in 1992 a Declaration concerning the South China Sea.

On 2 November 2002 the parties returned to the conflict of Paracel and Spratly Islands during a meeting of representatives of 10 countries - members of ASEAN, and the PRC. Then the parties worked out a 10-point declaration: the Declaration on the Conduct of Parties in the South China Sea, whose aim was to decrease the tension in the region and to improve the political climate. Until now it is the most complete proposal.

The solutions adopted in the declaration are not new. They were all proposals of earlier multilateral and bilateral mechanisms, but there are listed three specific solutions here. First of all: refraining from action towards currently uninhabited islands, reefs, rocks, which means that no new occupation should take place. This point also talks about building confidence measures, notification on exercises and sea maneuvers. Secondly, there is mention of continuing regular consultations about "observing" and monitoring the fulfillment of the declaration. This is not easy because according to the international law of the sea, the parties' right to fish overlaps with the disputed area. Thirdly, the parties agreed to develop a code of conduct.

After signing the declaration, attempts were made, often with good results, to undertake joint economic and scientific activities related to the islands. Even Vietnam, China and the Philippines, after some exploratory work, planned to conduct joint exploitation of oil and gas deposits by state-owned companies (Glosy, 2007, p. 165).

\section{SITUATION IN THE SOUTH CHINA SEA AND LEGAL SOLUTIONS IN THE SECOND DECADE OF THE $21^{\text {ST }}$ CENTURY}

In the second decade of the 21 st century, the problem around the archipelagos between China and some of the countries involved in the dispute i.e. the Philippines, Vietnam, partly Malaysia, escalated. Due to the expiration of the deadline for complaints about the continental shelf around the islands, in accordance with the Sea Law of 1982. In May 2009, Vietnam and the Philippines stepped up their efforts to seal its sovereignty over the islands. On February 2, 2009, the Philippine Parliament adopted the law "On the definition of the basic border line of the Philippine archipelago" (Kalaiaan archipelago). On March 10, the act was signed by the President of the Philippines, and on May 6, Vietnam and Malaysia brought a joint project to the UN to separate the shelf in the South China Sea beyond the 200-mile exclusive economic zone (Commission on the Limits of the Continental Shelf). A permanent representative of China at the UN suggested in a note addressed to the deliberators that the project of Vietnam and Malaysia should not be considered. At the same time, the Chinese map of the South China Sea was submitted to the UN commission, indicating the borders of the PRC, covering 80 percent of the disputed territories. On May 8, Vietnam submitted its project again, this time individually. It was followed by protest notes that were exchanged between Beijing and Hanoi (Portiakov, 2012, p. 34). 
ASEAN members did not agree on joint actions in this situation. In July 2012, the association's foreign ministers failed to unanimously adopt the statement for the first time, because Cambodia, the host of the summit, did not agree to include wording related to China's activities in the South-China Sea. In November 2012, again at the ASEAN summit, there was a problem with the appropriate formulation of the statement, because Cambodia sought to include in it the statement that the countries of the region would not seek to internationalize the conflict around the conflicting islands. This shows that it is difficult to achieve a uniform position in this matter, and the interests of countries which are more or less economically connected with China are in conflict. The positive effect of the talks was Indonesia's decision to take responsibility for the preparation of a new code of conduct for the parties in the South-China Sea, which was followed by the positive response of China.

In April 2013, events took place that exacerbated the dispute. It was the publication of the map by the Cartography Office of the PRC, on which the shoreline is marked in the shape of the letter $U$. This is the so-called line of nine-dash line, reaching all the way to Borneo, which the Vietnamese call "the Ox's tongue-line." On earlier maps it was used as a border dispute line. On the new one, it was claimed as an official state border. ASEAN countries pointed this out, and the Ministries of Foreign Affairs of Vietnam and the Philippines raised a protest against this act (Lokshyn, 2014, p. 254). China did not respond to these protests and made it clear that they were not satisfied with their response and rapprochement with the US in this field.

In May 2014, there were further escalations of the dispute. The situation arose after the Chinese oil installations HYSY 981 began drilling in the region of the exclusive economic zone of Vietnam and the continental shelf. In addition, China began building an artificial island in the Johnson South Reef area of the Spratly Archipelago. The Philippines protested against these actions on May 13, and the President of the Philippines in his statement held in June 4, 2014 called for the compliance with the 2002 International Policy Digest. These events led to an increase in nationalist anti-Chinese sentiment in both the Philippines and Vietnam.

The dispute in the South China Sea is directly related to American interests in the region. It is beneficial for the United States to maintain the status quo and do everything to not destabilize the situation. The US policy towards the South China Sea is based on two basic principles. The first is the policy of openness and access to water regions, which for strategic and economic reasons cannot be overestimated. Chinese control of the entire area could significantly limit this availability. China, as has been said, treat this area as its exclusive economic zone and use all means to limit the economic and military presence of other countries (Fravel). The second principle implemented in this region is the pursuit of stability that promotes economic development. There are several possible threats to the American oil industry, including the Vietnamese-Chinese conflict or the risk of small military operations.

While early official statements lacked full support for the solutions proposed by the Vietnamese and Filipino sides, during the escalation of the conflict in the second decade of the 21st century, the United States decided to openly support both positions in this conflict. Since 2010, Hillary Clinton, the US Secretary of State, has declared an increase in interest in the region and the strengthening of former alliances with Australia, Japan, 
South Korea, and among ASEAN countries, the Philippines and Thailand. In 2010, during the Summit of the Association, which was held in Hanoi, Hilary Clinton said that the US supports diplomatic settlement of territorial disputes and is against threats, and the initiatives to facilitate the construction of confidence measures are being prepared. For Vietnam, every help and political support was welcomed with approval. The US has proposed to internationalize the conflict over disputed archipelagos. Although ASEAN countries have stepped back from this proposal, Vietnam saw in this appeal a certain chance, even a form of publicizing the case and a pressure on China.

\section{DECISION OF THE PERMANENT COURT OF ARBITRATION AND FURTHER STEPS REGARDING THE CODE OF CONDUCT OF THE PARTIES}

In 2013, the Philippines referred the case to the Permanent Court of Arbitration in The Hague (PCA). On July 12, 2016, the Court issued a verdict taking into account the Law of the Sea, in which it accepted the Philippines's arguments and rejected China's claims based on historical arguments against the islands in the South China Sea (PCA Case $\mathrm{N}^{\circ}$ 2013-19). The court was still considering the status of land formations and rocks. Between fifteen allegations made by the Philippines, fourteen have been recognized.

China did not take part in the trial and found its sentences non-binding. Instead of China's place the judge was replaced by Polish judge professor Stanislaw Pawlak. ${ }^{1}$

Although the case concerned two parties, i.e. the Philippines and the PRC, Vietnam sent a statement in which it considers the Court's judgments to be binding on itself. Malaysia also sent a statement. It should be noted that the Court's judgment does not concern the most important issue of dispute islands with China, but it certainly opens the way to international law settlements. The most important conclusion of the verdict is the priority of UNCLOS Sea Law standards and other International Law standards. The court ruled that China has no historical rights to the disputed islands. Another important conclusion is the encouragement, resulting from the verdict, of dialogue and cooperation in the region in order to find solutions by interested parties.

This is not an easy task, especially in the region of Southeast Asia. ASEAN countries find it difficult to develop a unified position, because their interests are different towards China, which are the most interested party in controlling trade routes in the South China Sea. China is ASEAN's largest trading partner, and ASEAN is the third for China, the Association is one of the major investment directions of the PRC, and the new idea of Belt and Road is to be an impulse for development processes in the region. Hence, there is a precaution in formulating such assessments that can be read as anti-Chinese. At the summit in Vietnam, which took place immediately after the announcement of the verdict in 2016, the assessment of the PCA was omitted.

The new President of the Philippines Rodrigo Duterte found the Court's verdict a huge success, but he sees a way to achieve the goals in bilateral talks with China. Practically, the verdict, favorable to the Philippines has not been used.

${ }^{1}$ Based on the lecture of Professor Stanislaw Pawlak delivered during the seminar on the South China Sea at Warsaw University on 21.02.2020. 
Vietnam sees this situation as a serious threat to regional security. The President of SRV, Tran Dai Quang, speaking in Singapore on August 30, 2016, said that there would be no winners and defeated, if the further destabilization in the region was being increased, and then it would change into alone armed conflict (Thanh Nien News, 30.08.2016).

At the $28^{\text {th }}$ and $29^{\text {th }}$ ASEAN summits in September 2016, a statement was issued with a section on the South China Sea, with no reference to the PCA decision. In September 2016, Joint Statement on the Application of the Code for Unplanned Encounters at Sea in the South China Sea was issued (Join Statement On the Application Of the Code). It was based on a meeting between ASEAN states and China. The parties adopted the Code for Unplanned Encounters at Sea.

India has expressed its support for freedom of navigation and the principles set out in the UN Convention on the Law of the Sea. They call for a peaceful resolution of the conflict, while at the same time refraining from escalating tension, e.g. by organizing military exercises in the area of disputed waters and any other activities that may destabilize the situation in the region (Statement on Award of Arbitral Tribunal on South China Sea). In July 14, 2016, there was a meeting of the Ministers of Defense of India and Japan, held in New Delhi. During it both Ministers also emphasized their attachment to the UNCLOS principles. In this context it was expressed the approval of the verdict of the PCA's verdict and there were made attempts to respect the verdict by all parties (Joint Statement after the meeting Between Raksha Mantri and Japanese Defense Minister).

However, the United States has been emerging as Vietnam's most important ally regarding the dispute over the islands. It is the USA that uses various instruments to manifest dissatisfaction with the Chinese "nine-dash lines," designating claims over this waters. In January 2016, America sent a warship near Paracel Islands to manifest freedom of navigation. For the United States, despite the fact that it is not a party to the conflict, the verdict is favorable to their interests related to the freedom of navigation in this waters - this is the basic goal and principle emphasized by American leaders. The US Department of State calls for a peaceful resolution of the dispute in accordance with international law.

The US views on this issue did not change during the presidency of Donald Trump, as evidenced by e.g. the statement of the U.S. Secretary of State Michael Pompeo. In November 2019, he expressed understanding for the reasons of Vietnam and the Philippines in the conflict with China (Nguyen Ha). However, it should be noted that President Trump's activity in the South East Asia region has weakened in favour of North East Asia (Ang Cheng Guan, 2019, p. 229). In addition, Trump has killed all those initiatives of President Obama which were supposed to strengthen America's participation in South-East Asia (e.g. TPP). Such a move, have weakened the image of America in this part of the world.

Indonesia, called for restraint. Although Indonesia is not a claimant in the South China Sea disputes, it is concerned with China's nine-dash line. We read on the web page of the Ministry of Foreign Affairs of Indonesia: "Indonesia once again calls on all parties to exercise self-restraint and to refrain from any actions that could escalate tensions..." (The Jakarta Post 07, 2016; Laksma). Malaysia, another claimant in the dispute, urged the parties involved to show "self-restraint." "Malaysia cherishes peace and stability of 
the South China Sea and believes that China and all relevant parties can find constructive ways to develop healthy dialogues, negotiations and consultations while upholding the supremacy of the rule of law for the peace, safety and security for the region" (Lee Seok Hwai), reads the statement issued by the Ministry of Foreign Affairs of Malaysia. Brunei Darussalam issued no statement following the July 2016 ruling.

ASEAN states could not issue a joint statement following the ruling given the lack of consensus among ASEAN states. In May 2017, ASEAN-China Senior Officials' Meeting on the Implementation of the Declaration on the Conduct of Parties in the South China Sea took place in Guiyang, China (Joint Press Briefing). At the $30^{\text {th }}$ ASEAN Summit in April 2017 in Manila the Southeast Asian states issued a soft stance on the South China Sea dispute, allegedly bowing down to pressure from China (Mogato). There was a reference to the United Nations Convention on the Law of the Sea (UNCLOS). Also, there is a direct reference to the South China Sea issue. The statement reads: "We reaffirmed the importance of maintaining peace, stability, security and freedom of navigation and over-flight in and above the South China Sea" (Chairman's Statement). There is a call to observe the Declaration on the Conduct of Parties in the South China Sea. There is no reference, however, to the Hague ruling.

Nevertheless, it should be noted that Court's encouragement to negotiate has resulted positive way. In May 2017, China and ASEAN agreed on a "framework" for a code of conduct (COC) in the South China Sea ("The Economist", 27 May 2017, p. 43). A single draft of COC was first put forth in August 2018 with an agreement in November 2018 by two sides to finalize COC within three years, starting from 2019 (Nguyen Minh Quang). The Vietnamese fear that this term will allow China to benefit from the difference of opinion that appears in ASEAN on this subject. That is why the new ASEAN-X formula (Jump starting "ASEAN minus X"), which bypasses the consensus, could help Vietnam. Vietnam hopes to apply this formula on economic but also on strategic political issues. In this particular case, Vietnam hopes that reaching an agreement will not require the consensus of all ASEAN countries. However, the condition is that the ASEAN countries agree to use this formula in the event of security problems.

$35^{\text {th }}$ Summit, held in Bangkok (31.10-5.11.2019) demonstrated a positive spirit among ASEAN members. During the summit both China and ASEAN reaffirmed their commitment to complete a COC. Chinese Premier Li Keqiang declared: "We are willing to work with ASEAN, under the consensus that had been reached, to sustain long term peace and stability in the South China Sea, according to the timetable set for three years" (China Says Ready to Work With ASEAN). However, the problem is that the $\mathrm{COC}$ arrangement must have legal force.

In 2020 Vietnam took over the chairmanship of ASEAN. Vietnam set goals to strengthen regional unity and partnership, following the slogan "Cohesive and Responsive ASEAN." This means that activities related to the South China Sea and the completion of the Code of Conduct (COC) must be subordinated to this main objective. In addition, due to the Covid 19 pandemic, ASEAN priorities had to change. Nevertheless, in my opinion, Vietnam is prepared for long-term actions, based on diplomatic tools combined with a tough attitude, to solve problems related to the sovereignty of disputed areas. ASEAN will have to face up with the issues more consistently, by making greater use of quiet diplomacy. 
The crucial issue for ASEAN is whether the South China Sea conflicts will have an impact on ASEAN's unity. Surely, there is certain impact, but how strong is it? Following the July 2016 ruling, Laos issued no statement; also Myanmar, another country which enjoys strong economic ties with China, did not react to the ruling in a significant manner. China is putting pressure on countries which depend on China economically. Malaysia's stance is influenced by Chinese investment. The Philippine reaction is crucial, as it will influence ASEAN's stance on the matter. Beijing stubbornly maintains that it will not observe the PCA ruling.-China also maintains that the South China Sea issue should not affect relations between China and ASEAN, but this is difficult to put in practice. In reality, China-ASEAN relations are heavily influenced by the conflict. For ASEAN, it is hard to contest this situation as China is a much more powerful partner, both economically and in terms of international relations. Beijing strongly prefers a bilateral mode of resolving conflicts in the South China Sea, without any intervention from third parties. For example President Rodrigo Duterte has been offered a controlling stake in a joint energy deal by President Xi Jinping in exchange for ignoring an international arbitration on the South China Sea (CNN 13.09 2019). ASEAN is, however, a much weaker player (even taking into account that it is not a single country but an association of states), so from its perspective international support for its position is very much welcome. How will the conflict develop? It is hard to predict, but much depends on whether ASEAN will remain unified. But given ASEAN's economic connections with Beijing, ASEAN cannot simply go too far in criticizing China.

What are the sources of ASEAN disunity vis-à-vis the South China Sea conflict? One factor is the disagreement within the organization on whether to pursue integration or sovereignty (Linh Tong, 2016). Laos and Cambodia, heavily dependent on China in economic terms, chose to support China. Also Brunei chose to support China. Vietnam, due to its connections with China, opted for not "balancing" China together with the US and the Philippines. Finally, the ASEAN-style focus on consensus also limits the organization in its possible joint actions. A change could occur if the ASEAN countries agreed to apply the formula to security matters.

Even countries which are not direct claimants in the conflict, such as Thailand, find it hard to remain silent on the issue. A voice from non-claimant ASEAN members is very important for ASEAN's unity. And ASEAN's unity is crucially important for the future of the Association. Without unity among ASEAN members, the entire issue of peace in the region may become questioned. As it was mentioned in this article earlier, huge amounts of international trade pass through the South China Sea annually; therefore, the whole international community - not only China and ASEAN members - has stakes in that the area remains peaceful.

Indonesia, too, called for restraint. Although Indonesia is not a claimant in the South China Sea disputes, it is concerned with China's nine-dash line. We read on the web page of the Ministry of Foreign Affairs of Indonesia: "Indonesia once again calls on all parties to exercise self-restraint and to refrain from any actions that could escalate tensions..." (The Jakarta Post 07, 2016; Laksma E.A.). Malaysia, another claimant in the dispute, urged the parties involved to show "self-restraint." "Malaysia 
cherishes peace and stability of the South China Sea and believes that China and all relevant parties can find constructive ways to develop healthy dialogues, negotiations and consultations while upholding the supremacy of the rule of law for the peace, safety and security for the region" (Statement by Malaysia 12.07.2016), reads the statement issued by the Ministry of Foreign Affairs of Malaysia. Brunei Darussalam issued no statement following the July 2016 ruling (Chalermpalanupap T.).

The conflict has a tremendous influence on ASEAN. Given the issue's priority for ASEAN's survival, it is hard to be ignored - if ASEAN states remain conflicted towards the matter of the South China Sea, it will be hard to issue joint statements - and without joint statements (even at a minimal level), the message will be sent to the world that ASEAN is a very weak regional organization indeed. Some see the conflict as an "existential threat" to the unity of ASEAN (Linh Tong, 2016).Of course, lack of unity is beneficial to China which is known for its preference to proceed bilaterally.

One needs, however, to look at the question of the South China Sea not only regionally, but also globally. What if the conflict remains intensive, with involvement of both China and ASEAN states? It could lead to militarization. This will not be beneficial for anybody, within the region and beyond it. Even Indonesia, which has generally acted as a peacemaker in the region, has moved more forcefully towards demonstrating its capabilities. "Should military activities continue to intensify, ASEAN citizens will undoubtedly suffer from instability and insecurity" (Linh Tong, 2016). To avoid such an outcome, ASEAN must stay united and rational, and be a real partner for discussions with China on the South China Sea, which will certainly be on the agenda for long. Returning to the preliminary research hypothesis, it can be concluded that the status quo will be maintained under the current international conditions. My analysis shows that Vietnam will not give way to a diplomatic solution to the conflict taking into account its own interests and ASEAN verbally proclaiming peaceful solutions will not put Vietnamese interests at stake in relations with China.

\section{REFERENCES}

Ang Cheng Guan (2019), Southeast Asia after the Cold War. A Contemorary History, Nus Press Singapore.

Chairman's Statement, http://asean.org/storage/2017/04/Chairs-Statement-of-30th-ASEAN-Summit_FINAL.pdf (05.06.2017).

China Power, https://chinapower.csis.org/much-trade-transits-south-china-sea/ (15.11.2019).

China Says Ready to Work With ASEAN for South China Sea Peace, https://www.usnews.com/news/ world/articles/2019-11-03/china-says-ready-to-work-with-asean-for-south-china-sea-peace (20.02.2020).

CIA, The World Factbook, https:/www.cia.gov/library/publications/the-world-factbook/rankorder/ 2241rank.html (15.11.2019).

Commission on the Limits of the Continental Shelf (CLCS) Outer limits of the continental shelf beyond 200 nautical miles from the baselines: Submissions to the Commission: Joint submission by Malaysia and the Socialist Republic of Viet Nam, http://www.un.org/Depts/los/ clcs_new/submissions_files/submission_mysvnm_33_2009.htm (29.06.2017). 
Fravel T. M., The United States in the South China Sea Disputes https://www.swpberlin.org/fileadmin/contents/products/projekt_papiere/BCAS2012_Taylor_Fravel_web_final_ks.pdf (12.02.2016).

Glosy M. A. (2007), Stabilizing the back yard: Recent development In China's Policy Toward Southeast Asia, in: (eds.) J. Eisenman, E. Hegingotham, D. Mitchell, China and the Developing World: Beijing's Strategy for the 21st Century, M.E. Sharpe, Armonk, N.Y., pp. 150-188.

Hoang Viet (2009), ASEAN and the Prospect for Solution to Disputes In the South China Sea, in: The South China Sea: Cooperation for Regional Security and development, Hanoi.

Hurrell A. (1995), Regionalism In Theoretical Perspective, in: Regionalism In World Politics. Regional Organisation and International Order, (eds:) L. Fawcett, S. Hurrell, Oxford University Press, Oxford-New York.

International Policy Digest, http://www.internationalpolicydigest.org/2014/06/17/exposing-chinasartificial-islands-plan-spratlys/ (20.06.2014).

Join Statement On the Application Of the Code for Unplaned Encounters At Sea In the South China Sea, http://asean.org/storage/2016/09/Joint-Statement-on-the-Application-of-CUES-in-theSCS-Final.pdf (05.06.2017).

Joint Statement after the meeting Between Raksha Mantri and Japanese Defence Minister in New Delhi, http://pib.nic.in/newsite/PrintRelease.aspx?relid=147097 (13.11.2016).

Joint Press Briefing, http://asean.org/storage/2017/05/14th-SOM-DOC-Co-Chairs-Joint-Press-Briefing-Remarks-As-delivered-18-May-amen.pdf (05.06.2017).

Laksama E. A., The Domestic Politics of Indonesia's Approach to the Tribunal Ruling and the South China Sea, "Contemporary Southeast Asia" 38 (3), p. 382-388, https://static1.squarespace.com/ static/57e3c9e1d1758e2877e03ba5/t/5b3868130e2e72597373ffb7/1530423316116/CSEA_ The Domestic_Politics_of_Indonesias_Appr.pdf (12.06.2017).

Lee Seok Hwai, Malaysia calls for South China Sea dispute to be resolved by diplomatic and legal processes after Hague ruling, http://www.straitstimes.com/asia/se-asia/malaysia-calls-forsouth-china-sea-dispute-to-be-resolved-by-diplomatic-and-legal (05.07.2017).

Linh Tong, The ASEAN Crisis, Part 1: Why the South China Sea Is a Critical Test, "The Diplomat", 21 December 2016, http://thediplomat.com/2016/12/the-asean-crisis-part-1-why-the-southchina-sea-is-a-critical-test/ (09.07.2017).

Lokshyn G. M. (2014), Juzhno-kitajskije Morie: Do Mira i Spokojstwija jeshcho dalieko, (South China Sea: A Long Way to Peace and Agreement), Tichookieanskoje Obrazowanije 20122013, Moscow.

Metelitsa A., Kupfer J., Oil and Gas Resources and Transit Issues in South China Sea, http://asiasociety.org/files/SouthChinaSea_OilGas_brief.pdf (27.06.2017).

Mogato M., ASEAN gives Beijing a pass on South China Sea dispute, cites 'improving cooperation', http://www.reuters.com/article/us-asean-summit-idUSKBN17W02E (05.07.2017).

Nguyen Ha, Vietnam Gets a US Confidence Boost in China Sea Dispute, https:/www.voanews.com/ east-asia-pacific/vietnam-gets-us-confidence-boost-china-sea-dispute (05.11.2019).

Nguyen Minh Quang, Saving the China-ASEAN South China Sea Code of Conduct, https://thediplomat.com/2019/06/saving-the-china-asean-south-china-sea-code-of-conduct/ (29.10.2019).

PCA Case No 2013-19 In the matter of the South China Sea Arbitration, https://pca-cpa.org/wpcontent/uploads/sites/175/2016/07/PH-CN-20160712-Award.pdf (05.01.2016).

Portiakov V. (2012), O niekatorych osobiennostiach wnieshniej polityki Kitaja w 2009-2011 [On Selected Characteristic Features of China's Policy in the Years 2009-2011], "Probliemy Dalniego Vostoka”, No. 2. 
Sobczyński M. (2008), Uwarunkowania geopolityczne międzynarodowego sporu o Wyspy Spratly (Geopolitical Conditions of the International Conflict about Spratly Islands), in: Problemy rozwoju państw azjatyckich (Development Problems of Asian States), ed. J. Marszałek-Kawa, Wyd. Adam Marszałek, Toruń.

Statement on Award of Arbitral Tribunal on South China Sea Under Annexure VII of UNCLOS, http:// www.mea.gov.in/pressreleases.htm?dtl/27019/Statement+on+Award+of+Arbitral+Tribunal + on + South + China + Sea + Under+Annexure+VII+of+UNCLOS (13.11.2016).

Statement by Malaysia, Ministry of Foreign Affairs of Malaysia Putrajaya 12.07.2016, https://www. $\mathrm{kln}$. gov.my/web/guest/home?p_p_id $=101 \& p \_p \_l i f e c y c l e=0 \& p \_p \_s t a t e=\operatorname{maximized\& p\_ p}$ mode $=$ view\&_101_struts_action $=\% 2 \mathrm{Fasset} \_$publisher\%2Fview_content $\&$ 101_returnTo FullPageURL $=$ http $\% 3 \mathrm{~A} \% 2 \mathrm{~F} \% 2 \mathrm{Fwww} . \mathrm{kln}$. gov.my $\% 2 \mathrm{Fweb} \% 2 \mathrm{Fguest} \% 2 \mathrm{Fhome} \% 3 \mathrm{Fp} \_\mathrm{p}$ id\%3D3\%26p_p_lifecycle\%3D1\%26p_p_state\%3Dnormal\%26p_p_state_rcv\%3D1\&_ $101 \_$assetEntryId $=8393068 \& \_101 \_$type $=$content $\& \_101 \_u r l T i t l e=$ press-release-following-the-decision-of-the-arbitral-tribunal-on-the-south-china-seaissue \&redirect $=\mathrm{http} \%$ 3A\%2F\%2Fwww.kln.gov.my\%2Fweb\%2Fguest\%2Fhome\%3Fp_p_id\%3D3\%26p_p_ lifecycle $\% 3 \mathrm{D} 0 \% 26 \mathrm{p} \_\mathrm{p} \_$state $\% 3 \mathrm{Dmaximized} \% 26 \mathrm{p} \_\mathrm{p}$ _mode$\% 3 \mathrm{Dview} \% 26 \_3$ keywords $\% 3$ Dsouth\%2Bchina\%2Bsea\%26_3_struts_action\%3D\%252Fsearch\%252Fsearch\&inheritRed irect=true $(31.10 .2020)$.

Termsak Chalermpalanupap (2016), No ASEAN Consensus on the South China Sea, "The Diplomat”, 21 July, http://thediplomat.com/2016/07/no-asean-consensus-on-the-south-china-sea/ (05.07.2017).

Thanh Nien News 30.08.2016, http://www.thanhniennews.com/politics/vietnam-says-all-will-losein-any-south-china-sea-war-65659.html (24.01.2017).

“The Economist”, 27 May 2017.

The Jakarta Post 07, 2016, https://www.thejakartapost.com/seasia/2016/07/12/indonesia-urges-parties-to-respect-laws-following-south-china-sea-ruling.html (29.10.2019).

“The New York Times" 14.07.2016, https://www.nytimes.com/2016/07/15/world/asia/south-chinasea-dispute-arbitration-explained.html (17.06.2017).

US Energy Information Administration, https://www.eia.gov/beta/international/analysis_includes/ regions_of_interest/South_China_Sea/south_china_sea.pdf(17.06.2017).

\begin{abstract}
The South China Sea is the most inflammable area in the region of Southeast Asia due to its natural resources, commercial and political importance. The ASEAN countries directly involved in the dispute have conflicting interests, mainly related to their relationship with China, a pretender for the whole area. Therefore, attemps to settle the dispute are not successful. On July 12, 2016, the Permanent Court of Arbitration in The Hague issued a verdict taking into account the Law of the Sea, in which it accepted the Philippines's arguments and rejected China's claims based on historical arguments against the islands in the South China Sea. China did not take part in the trial and found its sentences non-binding but at the same time it has entered into a dialogue with ASEAN on the code of conduct (COC) in the South China Sea. The purpose of the article is to discuss how the parties are involved in the conflict, progress towards signing the Code of Conduct for the Parties in the South China Sea and the attitude of ASEAN countries to this conflict. Due to the degree of dependence of economies on Chinese influence, and relations with other powers, mainly the US, the behavior of individual countries is different. Hence the problem with the organization's cohesion and attempts to break the deadlock, which have
\end{abstract}


been unsuccessful so far. The basic research hypothesis that will be verified is to maintain the status quo in the South China Sea in the long run. At the same time, it was noted that Vietnam is prepared for long-term actions, based on diplomatic tools combined with a tough attitude, to solve problems related to the sovereignty of disputed areas. ASEAN will have to face up with the issues more consistently, by making greater use of quiet diplomacy. The theoretical basis of the article is Hurrell's theory of neorealism, which analyzes, among other things, the principles and objectives of regional organizations in the international environment. Hurrell assumes that all regional organizations cannot be understood differently from their regional balance of power and regional dominant forces policy and ASEAN's attitude proves this point of view.

Keywords: international relations, South China Sea dispute, Law of the sea, ASEAN, Vietnam

\section{ASEAN WOBEC SPORU NA MORZU POLUDNIOWOCHIŃSKIM PO ORZECZENIU TRYBUNALU ARBITRAŻOWEGO W HADZE}

\section{STRESZCZENIE}

Morze Południowochińskie jest najbardziej zapalnym obszarem w regionie Azji Południowo-Wschodniej, ze względu na jego zasoby naturalne, znaczenie handlowe i polityczne. Państwa ASEAN, bezpośrednio zaangażowane w spór mają sprzeczne interesy, związane głównie z ich relacjami z Chinami, pretendentem do całego tego obszaru. Dlatego też podejmowane próby uregulowania sporu nie przynoszą rezultatów. W dniu 12 lipca 2016 r. Trybunał Arbitrażowy w Hadze przyznał rację Filipinom w sporze z Chinami w oparciu o Prawo Morza i odrzucił racje historyczne Chin. Chiny nie brały udziału w postępowaniu i nie uznały wyroku, ale jednocześnie podjęły dialog z ASEAN nad Kodeksem Postępowania Stron na Morzu Południowochińskim. W artykule przybliżone są powody, dla których te rozmowy przedłużają się. Obecnie najbardziej zdeterminowanym członkiem ASEAN, który wszelkimi dyplomatycznymi metodami dąży do uregulowania sporu jest Wietnam. Celem artykułu jest omówienie w jaki sposób strony są zaangażowane w konflikt, jakie są postępy dotyczące podpisania kodeksu postępowania stron na Morzu Południowochińskim oraz postaw członków ASEAN wobec konfliktu. Ze względu na stopień uzależnienia gospodarek od wpływów chińskich oraz relacji z innymi mocarstwami, głównie USA zachowania poszczególnych państw są różne. Stąd problem ze spójnością organizacji i niemożnością przełamania impasu w tej sprawie. Podstawową hipotezą badawczą, która zostanie zweryfikowana jest utrzymanie status quo na Morzu Południowochińskim w perspektywie długoterminowej. Jednocześnie odnotowano, że Wietnam jest przygotowany na długofalowe działania, z zastosowaniem środków dyplomatycznych w połączeniu z twardą postawą. ASEAN będzie musiał stawić czoła tym problemom w sposób bardziej konsekwentny, wykorzystując w większym stopniu cichą dyplomację. Teoretyczną podstawą artykułu jest teoria neorealizmu Hurrella, który analizuje między innymi zasady i cele działania organizacji regionalnych w środowisku międzynarodowym. Hurrell zakłada, że wszystkie organizacje regionalne nie mogą być rozumiane inaczej niż przez pryzmat równowagi sił i polityki sił dominujących i postawa ASEAN udowadnia ten punkt widzenia.

Słowa kluczowe: stosunki międzynarodowe, konflikt na Morzu Południowochińskim, prawo morza, ASEAN, Wietnam 
